\title{
Unchaining African Economic Development: Entrepreneurship Education
}

\author{
Forje Lema Catherine ${ }^{1}$
}

\author{
${ }^{1}$ The University of Bamenda, North-West Region - Cameroon
}

\begin{abstract}
Africa lacks the vital knowledge necessary to establish a creative and innovative society capable of fostering economic development. Entrepreneurship knowledge is said to be the strength of economic development; it empowers and encourages people to start economic development activities. Presently, many educated Africans are those that do white collar jobs that produce very little economic developmental results. Africa needs people with entrepreneurship knowledge to enable them think creatively and be innovative. Such knowledge will enable a learning process that encourages engagement in economic development activities. People can only carry out economic development activities if they are educated to understand the factors that bring about such development. Economic development theories designed to help Africa economic development is unlikely to achieve that objective as long as the continent holds only to primary goods production. Porter (1998) in analysing the diamond of national competitiveness claims, natural resources is the only resource Africa has. From this perspective, Africa needs necessary knowledge that enables the production of finished goods. The objective of this study is to critically examine the role of entrepreneurship knowledge in economic development and how it orientates people to become creative, and innovative. Entrepreneurship's knowledge is believed to enlighten individuals and a society at large on what is needed for economic development to occur. Considering the view that developing entrepreneurs in the classroom is about developing an enterprising environments and approaches to learning in which entrepreneurial aptitudes and capabilities can flourish alongside business acumen and understanding, data is collected from management students in two universities in Cameroon and one university in Nigeria. The result is that Africa needs an entrepreneurial based that enlightens people to understand entrepreneurship and its role in economic development. The implication is that the study empowers people with knowledge required for business opportunity identification, creativity and innovation. The conclusion is that entrepreneurship should be taught at all school levels.
\end{abstract}

Keywords: Creativity; Economic Development; Entrepreneurship; Innovation; Knowledge; Learning

\section{Introduction}

The vision of many African countries, Cameroon for example, is to become an emerging economic power come 2035, but this is more a conceptual convenience. The type of knowledge needed to take the country to industrialisation is observed to be lacking. An educational system that orientates the people to be entrepreneurial is conspicuously absent. "Harsh et.al (2005) asserts that education is a powerful force in shaping assumptions that influence people's views." Critical realism suggests focus on the mechanism that is activated in order for a particular event to happen (Kevin and Ram 2012). "Critical theory suggests a type of knowledge in contrast to existing perspectives (Kevin and Ram 2012 op.cit). Complex economic development theories without knowledge that empowers people with the ability to understand the factors that bring about economic development is not likely to bring good result. Africa is a continent having vast natural resources; surprisingly this continent of gold and diamond is the poorest in the world in terms of economic development.

Many escalating economic development theories have been advanced with the hope that it will aid Africa's economic development, but the theories have not helped at all. Africa still remains underdeveloped. They need a type of knowledge deemed necessary to attain economic development first. Knowledge is a resource and also a source of economic development. Adam Smith (1776) succinctly pointed out that what constitute the real wealth of a country are goods and services available to its citizens through the use of acquired advantage "knowledge, skills and creative thinking." $\mathrm{He}$

This article is published under the terms of the Creative Commons Attribution License 4.0

Author(s) retain the copyright of this article. Publication rights with Alkhaer Publications.

Published at: http://www.ijsciences.com/pub/issue/2016-04/

DOI: 10.18483/ijSci.928; Online ISSN: 2305-3925; Print ISSN: 2410-4477 
claimed raw material is like manna from heaven and had very little value, therefore could not sustain a society's economy. Africa has enough of natural resources but cannot develop economically because it lacks the acquired resource, 'knowledge' that adds value to economic development.

It is observed that until recently, Africans placed great premium on grammar schools, ignoring the system of education that enables creativity such as commercial and technical education. This negligence oriented Africans to always look up to the government for employment instead of using the resources around them to produce goods and generating wealth. In order to understand factors influencing economic development, Africans need to acquire entrepreneurship and technical knowledge both for self and economic development. Cantwell, (1992) talks of capabilities and knowledge.

Small businesses are the backbone of a nation's economy, especially at the developmental stage. Success of these businesses requires entrepreneurship knowledge which embodies many skills Marshall (1842-1924), and a learning process. An example of what entrepreneurship knowledge and learning can do can be traced back in the 1960s when the upholster won first prize in a competition in Paris France. The winner came from the first Government Trade Centre, Ombe- Cameroon.

\section{Problem Statement}

Until recently in Cameroon when the teaching of entrepreneurship in universities was made compulsory, very few people understood entrepreneurship and its role in economic development. The misunderstanding is observed to still be going on. There is also a contradiction between entrepreneurship knowledge and learning. This contradiction often confuses people as to whether only entrepreneurship knowledge is important or both knowledge and learning. Entrepreneurship knowledge and learning are two different things although two sides of the same coin. Language plays a central role in its understanding and development. These contradiction needs to be clarified and the role of entrepreneurship outlined for people to understand.

\section{Objective}

The objective of this study is to present and discuss the assumptions which underlie the key frame of reference used to understand entrepreneurship knowledge and its role in economic development in order to promote and encourage creativity and innovation aimed at achieving economic development. Also, of concern is to find out where
Africa fits into Porter's idea of diamond of national competitiveness. The study also examines how entrepreneurship knowledge can be used to foster economic development within a framework based on 'planned behaviour' Ajzen (1991) in Africa.

\section{Conceptualisation of the term entrepreneurship}

An entrepreneur is an individual who establishes and manages a business for the principal purpose of profit and growth, and characterised by creativity and innovative strategic practices (Forje 2009; Kirby 2003; Schumpeter 1947). According to Marshall (1842-1924), the success of a business requires more than just creating the business. It requires entrepreneurship, which embodies the following skills.

- Knowledge of the trade;

- Technical knowledge:

- The ability to forecast;

- The ability to identify opportunities

- Cautious judgement

- Leadership capability

- The desire to improve performance.

From the definition of entrepreneurship, it is certain that it cuts across all walks of life. Therefore its teaching is likely to empower Africans with knowledge and the ability transform their raw materials into finished goods and also lead to proper taping of the hidden skills and spirits among the people.

Entrepreneurship has recently emerged as an incredible hawk, seen as embodying many economic developmental skills, and cutting through all disciplines including self-efficacy. Prior studies on economic development focus on international trade (Romer 1993; Schumpeter, 1934). The comparative advantage in trade strategy was highly emphasised as the best way for the economic development strategy for Africa. Today, the wave has changed to globalisation strategy. Globalisation strategy is based on competitive advantage in trade. According to Porter (1990), Competitive advantage is derived from entrepreneurship knowledge supporting Adam Smith's (1776) assertion many years ago. African countries as of now posses very little entrepreneurship knowledge. Porter (1990) ascertains this by pointing out that of all economic development resources, the only resource that Africans posses is natural resources. This expresses the crucial need for Africans to acquired entrepreneurship knowledge in order to make a headway in their economic development by adding values to their natural resources. . 
Entrepreneurship is characterised by critical thinking, creativity and innovative strategic practices (Kirby 2003; Schumpeter 1947). Such knowledge empowers people with the ability to think critically, be creative, innovative and understand the factors required for economic development. It becomes therefore imperative for Africans to acquire entrepreneurship knowledge as it embodies a host of other knowledge. Forje (2010) identifies entrepreneurship knowledge to contain among others Accounting/Finance, Management, Marketing and Organisation. These are factors embedded in economic development. Entrepreneurship in its broadest sense involves opportunity identification, creation, and assembling resources to pursue the opportunity. The process of acquiring entrepreneurship knowledge are two folds; it is acquiring knowledge and carrying out a learning process that empowers an individual with the ability to create and innovate. Innovation to enable sustainability originates from individual businessperson's learning process of accumulative and incremental problem-solving activity (Cantwell 1992). Entrepreneurship knowledge therefore becomes a key factor in economic development.

\section{Entrepreneurship knowledge acquisition and learning}

Entrepreneurship literature starts with the dominant idea that, entrepreneurship cuts across all walks of life, and goes beyond mere business opportunity identification and creation (Burns 2005; Schumpeter (1947) conceptualises an entrepreneur as an opportunity identifier, who through his/her creative and innovative behaviour creates jobs. All these characteristics of an entrepreneur explain the behaviour of the newly developed nations like China and India. Gerschenkron (1962) pointed out that the development paths differ between the developed and the developing countries. Naturally, it should not follow the same path because, apart from knowledge, developed and developing countries have different cultural background and historical development. Also, if the two worlds approach development differently, they both benefit from synergy effect. This occurs because entrepreneurial innovation has effects not only on the society in which it takes place but impact other societies as well.

Very little effort has been made to distinguish between entrepreneurial learning and entrepreneurial knowledge or what (Reuber, and Fisher 1993) refer to as experientially acquired knowledge. Experiential learning is described as the process whereby knowledge is created through the transformation of experience (Kolb 1984; Cope
2005) observed that, a better theoretical grasp of entrepreneurial learning is imperative as it is through learning that entrepreneurs develop and grow. Rae (2009) sees entrepreneurial learning as learning to recognise and act on opportunities and interacting with society to initiate, organise and manage ventures. Entrepreneurial learning is an experiential process where enterprise individuals continuously develop their entrepreneurial knowledge throughout their professional lives (Politis 2005). Entrepreneurial learning is also seen as a lifelong learning process, where knowledge is continuously shaped and revised as new experience takes place (Sullivan 2000). Developed nations understand this well and as such continuously seek new ways to keep the economic developmental pipeline flowing.

Kolb (1984) distinguishes between two basic and interrelated dimensions of experiential learning, i) acquisition (entrepreneurial experience) and ii) transformation that is considered equivalent to entrepreneurial knowledge. Kirzner (1979) sees entrepreneurial knowledge as a rarefied abstract type of knowledge - knowledge of where to obtain information and how to deploy it. Acquired knowledge generates routines and decisional procedures. African countries, Cameroon in particular, now emphasises the acquisition of entrepreneurship knowledge in schools, but has not put in place mechanism for acquiring entrepreneurial experience. Putting in place mechanism for acquiring entrepreneurial experience requires the creation of small businesses. Zoltan (1999) argued that the creation of small businesses by developing countries imposed excess costs on the economy as a result of scale production that is too small to be efficient. The author forgets that at the start of any economic development, learning has to take place. Entrepreneurship learning is similar to research. Cost must be incurred in order to acquire knowledge for develop.

African countries have the raw materials, and should use it to acquire entrepreneurship knowledge and learning, because learning also enables the creation of other new resources to sustain development. Today with the globalisation trade strategy, small business creation are highly encouraged, and emphasised. Such encouragement has its dark side as well; Without the acquisition of entrepreneurship knowledge that enables Africans to engage in production, they may again be encouraged to embark on creating small retail shops to market the products of foreign producers instead of striving to produce finish goods that will help to foster their economic development. Entrepreneurship learning everywhere is costly and takes time whether it is carried out in a developing or developed country. That other nations 
are economically developed is no magic. Drucker (1985) argued that entrepreneurship is a practice and not magic or mystery and it has nothing to do with genes. It is a discipline and, like any discipline, it can be learned. Universities only need to tailor-made courses (Cummings 1999) and project based courses with inter-disciplinary groups and action learning programs. This approach is likely to promote entrepreneurship spirits in schools and in societies. The university management should strongly encourage entrepreneurial activities among faculties through several actions: developing income generating products and marketable services. Brain trust projects should be encouraged and sponsor by the authorities concern.

From the various views presented, it is possible to imagine a pathway to entrepreneurship knowledge and learning acquisition. This is illustrated in table 1.

Table 1: Pathway to Entrepreneurship knowledge and Learning acquisition

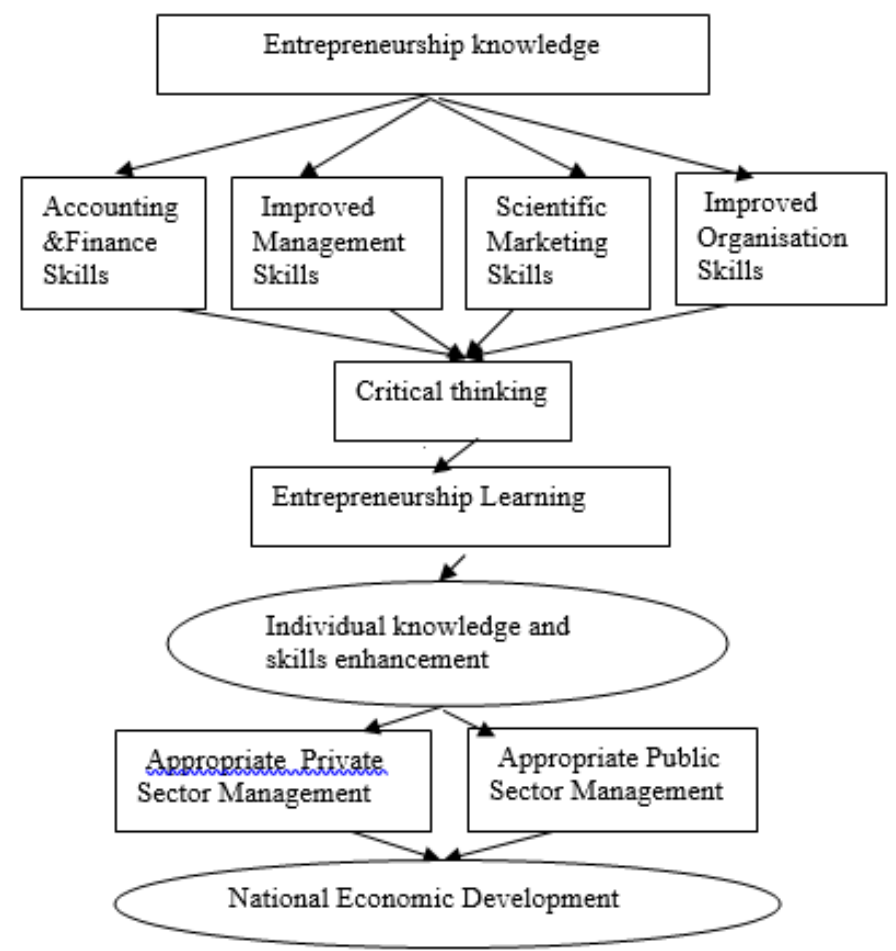

Source: Forje L.C.

Without the type of knowledge that enables Africans to think critically and reason entrepreneurially, the best theories of economic development will not develop Africa. It will only lead to confusion and exploitation of the fast depleting natural resources they have. Now, emphasis is on innovation; innovation is another economic development means, but business opportunity identification must take priority over innovation, because innovation sprouts from existing businesses. Given entrepreneurship knowledge, full fledge businesses can be created to add more values to economic development and also allows for full utilisation of the resources around. In

These are illustrated in table 2 .

Table 2. Porter's Diamond of National Competitiveness' examining the competitive strength of countries in economic development, "Porter (1998) developed four facets which he calls the 'diamond of national competitiveness'; the facets are:

1. The existence of resources (human resources and research and information)

2. A business environment that invest in innovation

3. A demanding local market

4. The presence of supporting industries 


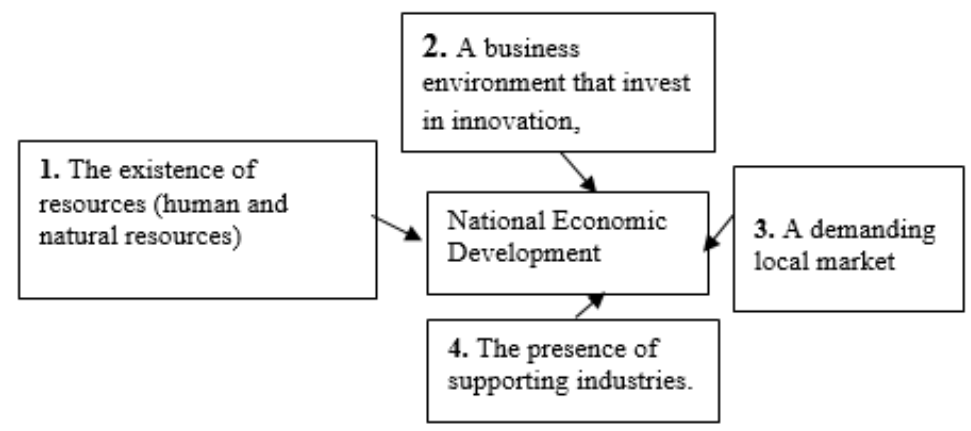

Source: Porter Michael E. (1998). "Competitive advantage" of Nations and adapted

Porter argues that for many developing countries (Africa in particular); natural resources may be the only part of the diamond they can boost of, which suggests that African countries are still unable to transform their natural resources into finished consumable goods, which in Adam Smith's view, propels a nation's economic growth.

\section{Methodology \\ Data Collection}

Questionnaires were designed and administered in two universities in Cameroon and in one university in Nigeria (Enugu State) to management students in their final year, 250 in number in each country. The choice of Nigeria and especially Enugu State was due to its historical past relationship with Cameroon. Enugu State and Southern Cameroon had many things in common during the colonial period. During this period, the Igbos were more business adept than Cameroonians and operated small businesses in the then Southern Cameroon, now South and North West Regions of Cameroon. Questions are based on Porter's facets of diamond, the level of entrepreneurship knowledge in the two societies and the idea of teaching entrepreneurship at all school levels. Questions were the same for both countries. Data is analysed descriptively. Data is presented in Table 3. Interviewees were asked to rate their views within the range of, 1,2 . 3. 4. 5, with 5 being the highest and 1 the lowest opinion. Analysis is both qualitative and quantitative using descriptive statistics.

Key question to quantify result were,

1. From the above table, where in your opinion does Cameroon fit, equally for Nigeria, as far as Porter's Diamond of national competitiveness is concern? Rate from the perspective of African economic development?

2. How will you rate the idea of teaching entrepreneurship at all school levels? Indicate by assigning scores ranging from 1-5.

3. What in your opinion is the level of entrepreneurship knowledge in your society?

Data is presented in table 3.

Table 3. Data Presentation

\begin{tabular}{|c|c|c|c|c|c|}
\hline \multirow[t]{2}{*}{ Nr. } & \multirow[t]{2}{*}{ Opinions } & \multicolumn{2}{|c|}{ Countries/Scores } & \multicolumn{2}{|c|}{$\begin{array}{l}\text { Responses } \\
\text { Out of } 250 .\end{array}$} \\
\hline & & $\begin{array}{l}\text { Cameroon } \\
250\end{array}$ & $\begin{array}{l}\text { Nigeria } \\
250\end{array}$ & $\mathrm{C}$ & $\mathrm{N}$ \\
\hline 1 & The existences of natural resources & 4 & 3 & 225 & 145 \\
\hline 2 & $\begin{array}{l}\text { A business environment that invest } \\
\text { in research and innovation }\end{array}$ & 3 & 4 & 106 & 182 \\
\hline 3 & A demanding local market & 3 & 4 & 196 & 235 \\
\hline 4 & The presence of supporting industries & 2 & 3 & 95 & 215 \\
\hline 5 & $\begin{array}{l}\text { Entrepreneurship teaching at all } \\
\text { School levels needed }\end{array}$ & 4 & 4 & 235 & 215 \\
\hline 6 & $\begin{array}{l}\text { Knowledge of Entrepreneurship } \\
\text { Present in the country }\end{array}$ & 2 & 4 & 105 & 175 \\
\hline
\end{tabular}

$\mathrm{C}=$ Cameroon, $\mathrm{N}=$ Nigeria

Source: Forje L.C 
This strategy is to formalise 'Forced economic development' based on knowledge. This is in line with Kirby (2003) assertion that, personal peak performance does not result from a personal talent or trait, it has to be developed. The pie diagrams presents the various opinions.

\section{Existence of natural resources}

Cameroon

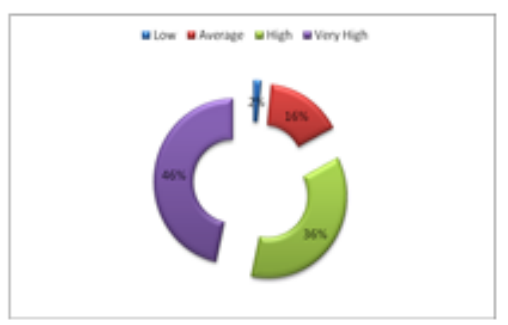

Nigeria

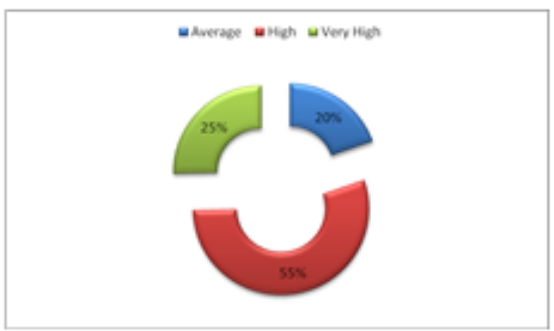

Business environment that invest in research and innovation

Cameroon

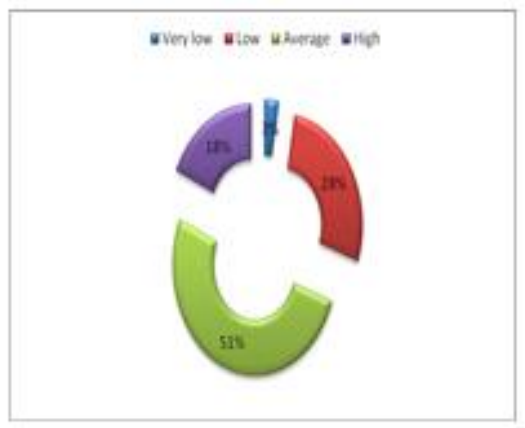

Nigeria

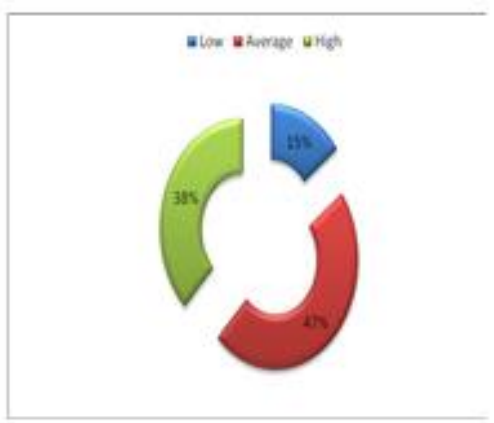

Presence of supporting industries

Cameroon

Wone wery low alow wAverage

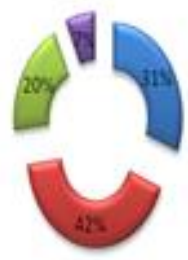

Nigeria

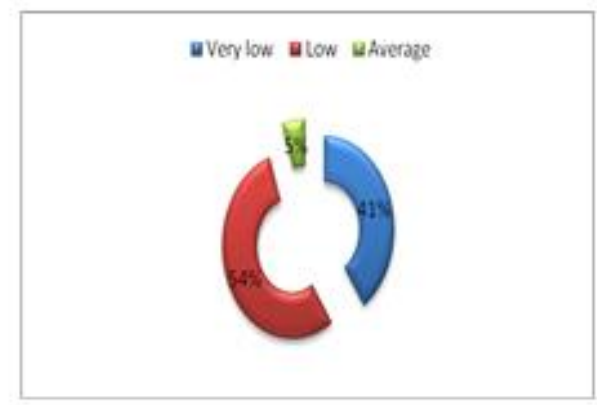




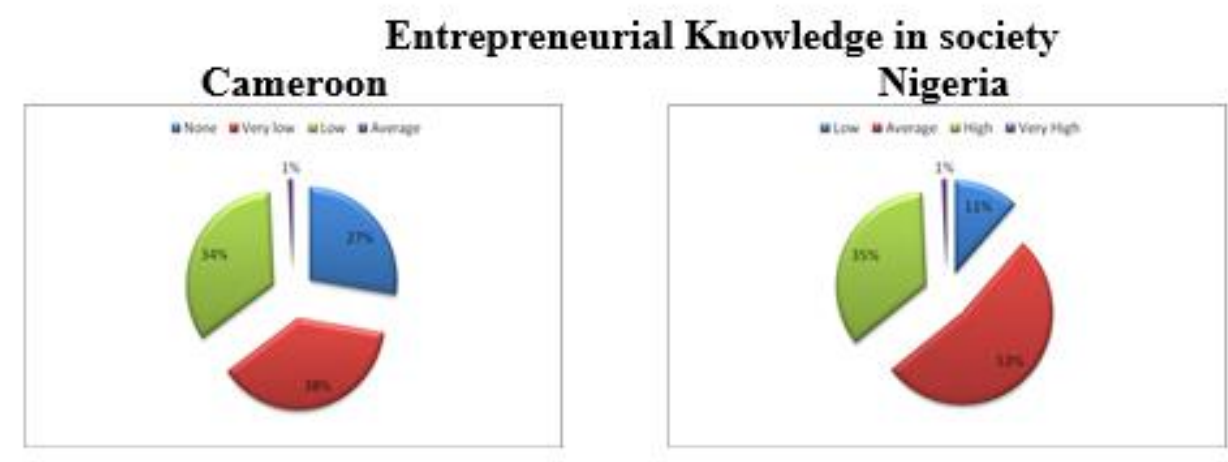

Demanding local market
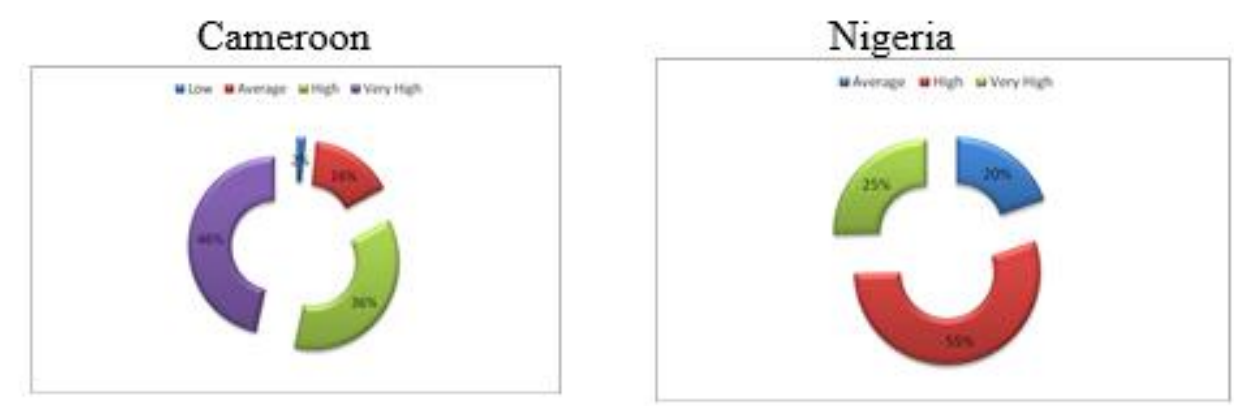

Business environment that invest in research and innovation
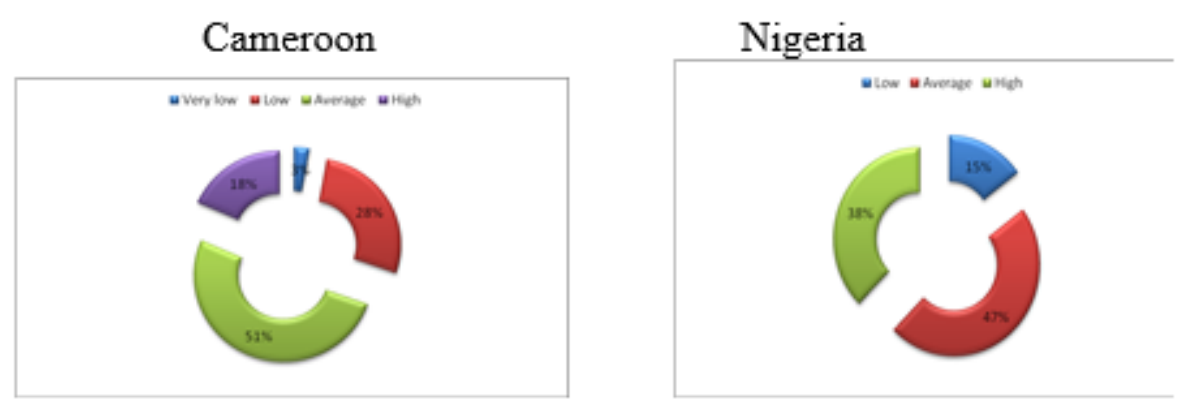

\section{Presence of supporting industries}

\section{Cameroon}

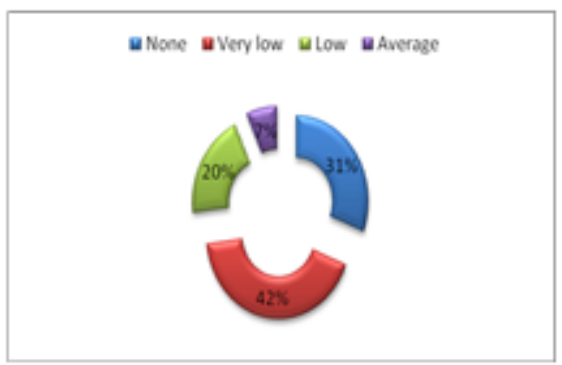

Nigeria

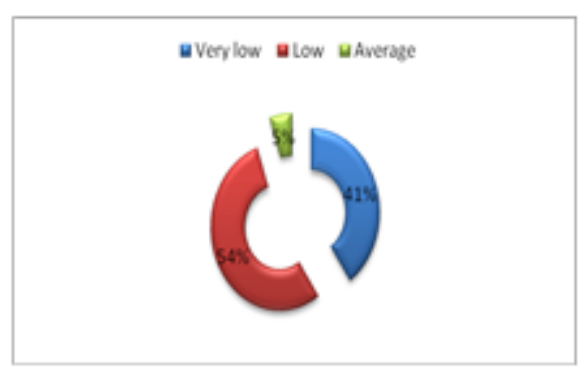


Bar chart 1 summarises the opinions given

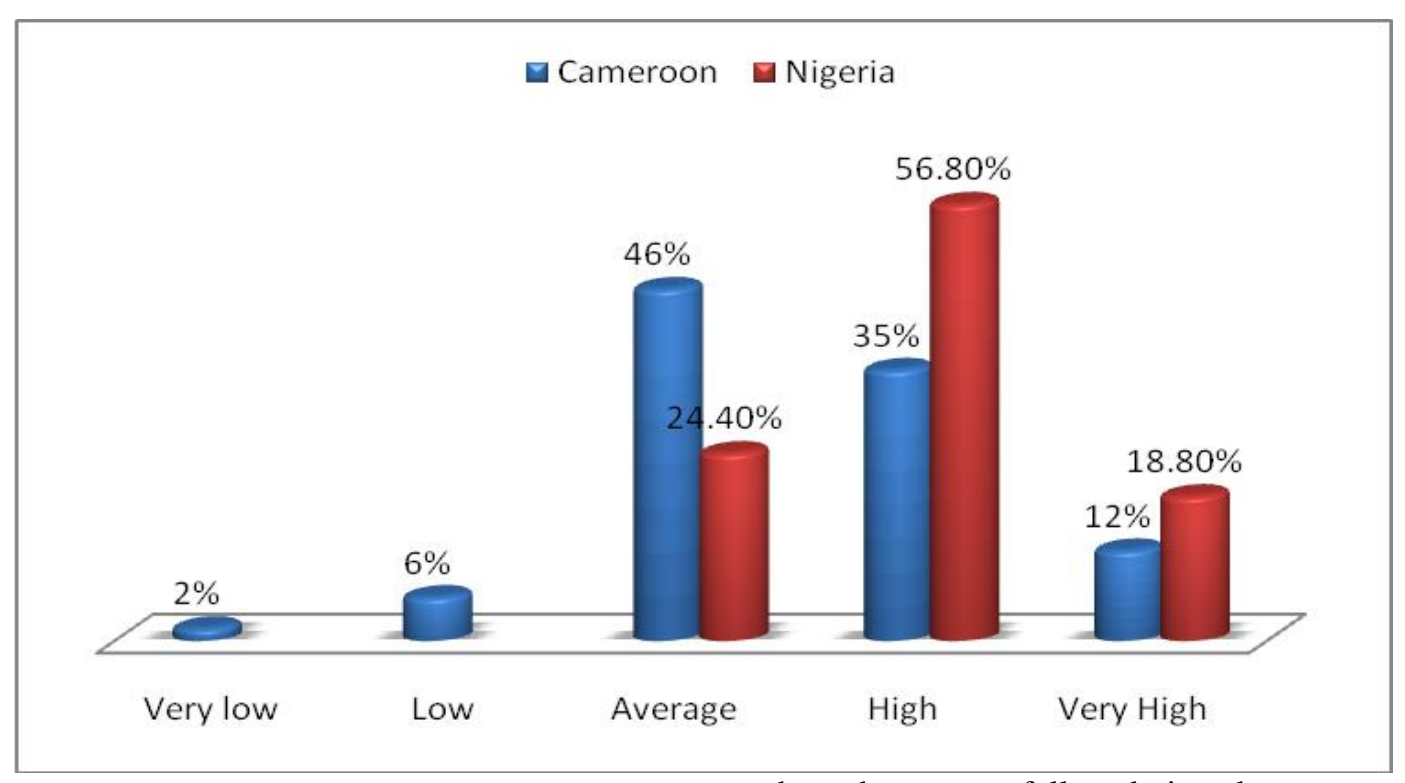

The teaching of entrepreneurship to prepare Africans for an effective and efficient transition from primary to manufacturing based products is of great importance. Teaching the subject as FreduaKwarteng (2006) suggests would encourage selfemployment among school graduates as they develop positive attitude toward self-employment, personal responsibility and self-reliance. Lack of entrepreneurship knowledge inhibits people from contributing to the economic development of their country, hence economic development is often seen as something that should only come from the government. With entrepreneurship knowledge, people, will also be empowered with the ability to work successfully in any sector since entrepreneurship knowledge cuts across all disciplines. Duty consciousness, organisation, management can also be seen as factors of economic development. The knowledge also purports selfdevelopment as well which is very much needed in Africa. Lack of duty consciousness slows down work as well as brings about mismanagement of resources. Entrepreneurship knowledge encourages an attitude of a new mindset that creates a positive association between entrepreneurship, individual success and the creation of wealth through creative actions.

One of the major weaknesses in the process of economic development of most African countries is the lack of a strong entrepreneurial base within the private sector Forje (2009). This weakness is manifesting itself at a time when there is increasing complexities and intense complication in the global market. This calls for a greater investment of effort in the empowerment of people, especially the youths through a carefully designed entrepreneurship education to meet the challenges posed by the entrepreneurship knowledge based global market characterised by high and growing competition. Harsh et.al (2005) asserts that education is a powerful force in shaping assumptions that influence people's views. From Harsh's perspective, the short comings in the syllabus of many African countries can be seen.

Entrepreneurship studies did not feature in the school curriculum of many African countries until recently. This immediately suggests that they lack this vital economic developmental knowledge. From this perspective entrepreneurship education and policies are needed for Africa to reflect on their economic development. Education curriculum needs to be structured in a way that many students graduate as job creators and not job seekers (Forje 2009).

\section{Findings, discussion and analysis}

There is opinion differences between Cameroon and Nigeria. Nigerians have always been entrepreneurial even during the colonial period. They practiced business networking and were more business oriented than Cameroonians. Views on table 1 suggest that the Cameroon government needs to emphasize the teaching of entrepreneurship at all school levels. It is imperative that the country embarks on innovative education that prepares the people towards industrialisation. Business studies in universities in Nigeria picked up in the 1960s as compared to Cameroon. The concept of entrepreneurship was commonly mentioned in Nigerian universities even before independence. Entrepreneurship concept slowly entered in the syllabus of Cameroon universities in 2007. People 
are still struggling to understand what it means and its role in economic development. Hence for Africa to embark on successful economic development journey, entrepreneurship needs to be taught to better prepare people and more specifically the youths to be creative and innovative. Such teaching will empower citizens with appropriate knowledge that prepares them for industrialisation which is a sure path to economic development.

A critical examination of Porter's Diamond of National Competitiveness' suggests that most African countries still hold on to natural resources as their main economic power. Their natural resources need to be given added value to make them economically useful. Also, many Cameroonians still see governments as the lone source for economic development. The role of the individual in the nation's economic transformation is still not well understood. The knowledge of entrepreneurship with its creativity and innovative role is likely to influence citizens to understand their role in the economic development of a nation and contribute their own share.

According to Timamy (2007), the failure of Africa to spur economic growth is many and varied; crucial one is lack of entrepreneurship knowledge capable of fostering a dynamic entrepreneurial culture and developmental momentum. In the past, sources of production have always been, "labour" and "capital" In recent years, these traditional factors have changed. Labour and capital have lost their significance. The importance of inputs like; information and knowledge have risen (Stam 2007). This renders countries that do not invest in information and knowledge vulnerable to foreign exploitation of their raw materials. Information dissemination in some African countries is poor, Cameroon for example. Information takes a long time to get to people. The mass media need to be fully engaged in information dissemination because it is an important input mechanism in the present globalisation trade strategy. Knowledge is the master key in any economic development process. This leads me to share an experience 1 had when travelling to a nearby town on a bus. While on the bus, a man sitting next to me looked at the forest as we drove along and said:

"We have a tongue in our hands yet fire is burning us."

There is a culture in Cameroon where a piece of carved bamboo in the form of a tongue is used to take out or regulate burning charcoal in fire instead of using ones hands. The interpretation is that, we have all the necessary natural resources yet drowning in poverty. This ascertains the fact that people are beginning to be aware of the fact that the country needs to put in place mechanisms and the element required to transform those forest into wealth and pull people out of poverty. It also confirms Porter's (1998) claim that natural resources are the only factor of economic development that the African continent has. A well articulated planned education is required to move the continent towards economic development. Transforming natural resources into finished goods stimulates domestic demand and this generates economic growth and promotes sustainable welfare for all. Such transformation requires specific knowledge. The rapidly increasing shift from natural resource-based to knowledge-based economies as (demanded by globalisation) calls for policy reorientation (Hurst 1976:21).

The above presented episodes expresses a learning exercise that indicates the need for knowledge, creativity and innovation in order to put the country's natural resources into proper use. Glaser and Strauss (1967) claim, listening and examining what people in the society say, can shed lights on many things we often take for granted or do not even see. The starting point of most economic development is localised. Cole (2004) claims, entrepreneurship deals with relativities, not absolutes, and it is situational. Gerschenkron (1962), a contemporary of Schumpeter-added a unique historical perspective to the established story of entrepreneurship and economic development, namely the idea that entrepreneurs are vital to economic development. Lack of entrepreneurship knowledge influences African governments to act contrarily to their desire. Cameroon for example is trying to encourage domestic consumption, and at the same time psychologically giving foreign products superior position. For example,

"According to a TV interview on $24^{\text {th }}$ April 2009, 7:30 News, Ndop rice producers complained about government's discriminatory taxing policies that favour foreign rice importers and disfavour domestic rice producers. "

Such attitude indicates lack of economic developmental knowledge. Ndop rice is domestically produced and needs to be protected by government and there is also the need to encourage its consumption. Giving favourable tax conditions to foreign rice importers over domestic producers brings psychological problems of putting domestic products in an inferior position. In Cameroon, high price according to the people implies high quality. They never go into the problems of analysing transport cost and other importation surcharges. 
The study provides evidences that confirm Porters view that, for many African countries natural resources is the only part of the facet of diamond of national competitiveness. However, the Good news about the diamond of national competitiveness is that at the most basic level of economic development, is the "resource-driven stage", competitive advantage is determined by resources such as low cost labour and access to natural resources (Porter 1998). This strengthens the economic starting point of many African countries. The implication therefore is that, Figure 2: Impact of entrepreneurship knowledge-learning

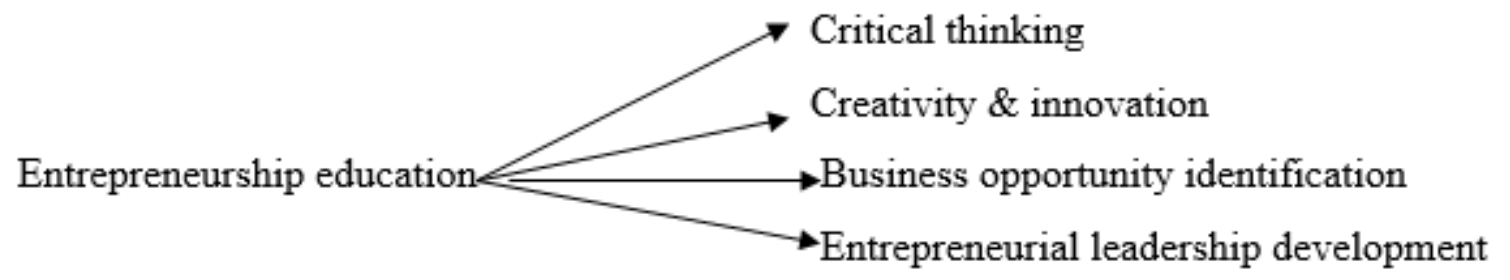

Figure 2, suggest that entrepreneurship will enable critical thinking and creativity that would open a variety of ways on how to transform raw materials into finished goods that would raise prices, and also expand the stock of raw materials by developing new ones. All these knowledge are likely to promote economic development.

Kuada (2009) bemoans that entrepreneurship has been seen by Africans as isolated and discontinuous innovative efforts made by individuals with Calvinistic attitudes to work and life. This attitude prevents African entrepreneurs from adopting good business practices that can sustain their businesses and create opportunities for employment. Although entrepreneurship is a fairly new concept in Cameroon, effort needs to be made in educating people to understand the role of entrepreneurship in economic development, appreciate and orientate themselves toward creativity and risk taking. Africa is well endowed with natural resources, but this is not enough to bring about economic development. Many Africans still see economic development as alien - dropping from somewhere; probably heaven. It is not brought about by people like them. An entrepreneurship society will be created, and people will be creative, think and act entrepreneurially. Entrepreneurship education will create a natural path in Africa that can be characterised as an evolution in the African economic development

\section{Conclusion}

It has been substantially argued that entrepreneurship teaching is likely to improve the skills of people in all walks of life, as such, whether entrepreneurship teaching results in business creation or not, it will still go a long way to improve people's ability to be creative, innovative, be ethical, duty conscious and empowering Africans with knowledge that enables them to be creative, identify business opportunities and act upon is designing a tongue that will save them from burning themselves with fire as the folktale mentioned elsewhere in this suggests. Given appropriate knowledge and direction, people will become creative and innovative. Policy makers will also be aware of how to select policy variables and make sensible economic development decisions. Figure 2 outlines the effect of entrepreneurship teaching on the population.

\section{Critical thinking \\ Creativity \& innovation \\ Entrepreneurial leadership development}

better plan the use of their resources. These are qualities that contribute to the building of a sustainable economic development capacity of a nation. The marriage between entrepreneurship teaching and technical education is imperative to benefit from the continents' natural resources.

A major aid to creativity is setting aside funds earmarked specifically for use in developing creative ideas. Many creative ideas in Africa are never developed due to lack of funds. It is in this light that Cantwell's idea of capabilities is important. Capabilities uncompress both finance and skills. Making entrepreneurship learning a must and setting apart funds for its achievement is a groundbreaking innovation that would change the African continent's face in terms of economic development.

Business opportunities exist all the time, both internally and externally. What the people need is appropriate knowledge and skills to identify business opportunities and transform them into wealth creating products. This study argues that Africa is a continent blessed with a variety of resources, (agricultural products, cultural diversity, forestry, fishery, touristic sites and minerals), without entrepreneurial knowledge, these resources cannot be transformed into economic development tools.

African countries need to rethink critically and realistically. Proper training, education and guidance should prepare people and promote economic development. This begins with an excellent mastery of core entrepreneurship characteristics and generating entrepreneurial spirit. From this research, entrepreneurship as a subject will have to be actionoriented. This will require government undertaking constructive policy measures and institutional 
reforms; such as training teachers and providing financial assistance for willing and committed graduates to create small businesses, generate income, help themselves, contribute to the economic development of the country and also promote entrepreneurship spirit in the society. The brain trust competition introduced in Cameroon universities is a good innovative step forward. The greatest legacy Africa need most is entrepreneurship education.

\section{References}

1) Adam, Smith in Hurst James Willard (1976:p16) Law and Markets in United States History, Different Modes of Bargaining. Among Interests. The University of Wisconsin Press._Harvard Business School Press.

2) Ajzen, I., (1991) The theory of planned behaviour. Organisational Behaviour and Human Decision Processes, vol. 50, pp. 179-211.

3) Burns, Paul (2005) Cooperate Entrepreneurship, Building an Entrepreneurial Organisation. Palgrave.

4) Cantwell, J.A (1992) Japan's industrial competitiveness and the technological capabilities of the leading Japanese firms, in Forje Lema Catherine's (2015), New innovation and sustainability in a developing country. The case of Cameroon. International Journal of Business Management and Administration May 2015 Vol. 4. No. 1

5) Cole, A.G. (2004) 'Management Theory and Practice.' Thomson.

6) Cummings, W.K. (1999) The service orientation in academia or who serves in comparative perspective. In Higher education at the cross roads, ed. I Fagerlind, I, Holmesland and G. Stromqvist, 223-232 Stockholm: Institute of International Education, Stockholm University.

7) Drucker, Peter (2000).Putting more now in knowledge. Forbes 165 (11):84-8.

8) Forje, Lema Catherine (2010) Recreating Government: Entrepreneurship and Proverbs in Cameroon Public Administration. Journal of Public Administration and Policy Research, Online. March 2010 issue 2(2).

9) Forje, Lema Catherine (2008) Small Businesses in Cameroon: Key Factors Impeding their Growth. Tropical Focus. The International Journal Series on Tropical Issues Volume 9 Number 3 pp 9-23, September 2008 Pacificam Douala: Printed on behalf of Tropical Focus.

10) Forje, Lema Catherine (2009) Empowering the Youth through Entrepreneurship Education. Cyprus International Journal of Management. Vol. 14, Nr.1 pp 26-45, Autumn 2009 Cyprus.

11) Fredua-Kwarteng $Y(2006)$

12) www.ghanaweb.com/GhanaHomePage/feaatures/artikel.php ?ID $=98785 \&$ comme

13) Gerschenkron, Alexander (1962) Economic backwardness in historical perspective. New York: Frederick A. Praeger Publishers.
14) Harsh K. Luthar and Ranjan Karri (2005) Exposure to Ethics Education and perception of linkage between organization Ethical Behaviour and Business Outcomes. Journal of Business Ethics. Vol. 61. Nr. 4. Pp353-368

15) Hurst, James Willard (1976) Law and Markets in United States History, Different Modes of Bargaining Among Interests. The University of Wisconsin Press._Harvard Business School Press.USA.

16) Kevin, Mole with Monder Ram (2012) Perspectives in Entrepreneurship. Palgrave Macmillan.

17) Kirby A. David, (2003). Entrepreneurship. McGraw-Hill, Education UK.

18) Kirzner, I.M. (1979) Perception, opportunity and profit: Studies in the theory of entrepreneurship. The university of Chicago Press.

19) Kuada John, (2009) "Gender, Social Networks, and Entrepreneurship in Ghana”. Journal of African Business, 10:1:85-103. Aalborg University, Aalborg, Denmark

20) Kolb, D. A. (1984) Experiential learning: Experience as the sources of learning and development. Englewood Cliffs Prentice Hall

21) Marshall, (1842-1924) In Kirby A. David, (2003). Entrepreneurship. McGraw-Hill, Education UK.

22) Miclean, M. (2004) Learning to do as a pillar of education and its links to entrepreneurial studies in higher education: European contexts and approaches. Higher Education in Europe 29:221-231.

23) Politis, D (2005) The process of entrepreneurial learning. Conceptual framework. Entrepreneurship Theory and Practice 29 (4): 399-429.

24) Porter, Michael E. (1998) "Competitive advantage of Nations."

25) Rae, D (2009) Connecting entrepreneurial learning and action learning in student-initiated new businesses ventures: The case of speed Action Learning. Research and Practice 6 (3): 289-303.

26) Reuber, R.A. and E.M.Fischer( 1993) The learning Experience of Entrepreneurs In the Frontiers of Entrepreneurship Research, ed. N.C.Churchlill, S. Birley W.D

27) Schumpeter, J.A. (1947) The Creative Response in Economic History. In The Economics and Socialism of Capitalism. Princeton University Press New Jersey.

28) Stam, C. (2007) "Knowledge Productivity designing and testing a method to diagnose knowledge productivity and plan for enhancement. Dissertation, University of Twente, Publication Enschede September.

29) Sullivan, R. (2000) Entrepreneurial learning and mentoring. International Journal of Entrepreneurship Behaviour and Research 6 (3): 160-75.

30) Timamy Khalil, M.H., (2007). "The Political Economy of Technological Underdevelopment in Africa.

31) Zoltan, ACS J. (ed) (1999). Are Small Firms important? Their Role and Impact. Kluwer Academic Publishers. 